\title{
Approximation to the Composition and Biodiversity of Saltlicks Forest for Two Indigenous Communities in the Colombia Amazonas Trapeze ${ }^{1}$
}

\author{
Ana Maria Monsalve-Cuartas' ${ }^{1}$, Francisco Castro Rego'², Ignacio Sanchez ${ }^{3}$ \\ ${ }^{1}$ University of Lisbon-Higher Institute of Agronomy (ISA), Lisboa, Portugal \\ ${ }^{2}$ Higher Institute of Agronomy (ISA), Lisboa, Portugal \\ ${ }^{3}$ Francisco Jose Caldas District University, Bogotá, Colombia \\ Email: Laoma468@gmail.com, frego@isa.utl.pt, sancheznach@gmail.com
}

How to cite this paper: Monsalve-Cuartas, A.M., Rego, F.C. and Sanchez, I. (2019) Approximation to the Composition and Biodiversity of Saltlicks Forest for Two Indigenous Communities in the Colombia Amazonas Trapeze. Open Access Library Journal, 6: e5429.

https://doi.org/10.4236/oalib.1105429

Received: April 25, 2019

Accepted: August 25, 2019

Published: August 28, 2019

Copyright $\odot 2019$ by author(s) and Open Access Library Inc.

This work is licensed under the Creative Commons Attribution International License (CC BY 4.0).

http://creativecommons.org/licenses/by/4.0/

\begin{abstract}
Tikuna and Uitoto indigenous communities believe that Saltlicks are sacred natural spaces (SNS) in the Amazon Rainforest, health and nutrition spaces of important species of fauna, especially mammals and birds. The perception, knowledge, use and spiritual management of saltlicks under the values of these indigenous communities help the conservation of more than 130 species of flora identified in forest inventories in saltlicks. The purpose of this article is to identify the composition and biodiversity of the forest in a sample of 11 saltlicks (6 in the TICOYA Resguardo ${ }^{2}$ in the San Martin de Amacayacu $(\mathrm{SMA})^{3}$ area, Tikuna community, and 5 in RITU Resguardo, LosKilometrosarea, Uitoto community), recognizing genres (or species when were possible) and frequently botanical families. The data were obtained through field work with forest inventories by transects of $4 \times 50$ meters made in the years 2015, 2016 and 2017, with help of guides and knowledgeable flora elders from both communities. As a conclusion, the saltlicks samples in both Resguardos have
\end{abstract}

\footnotetext{
${ }^{1}$ This article is part of the thesis developed of the SUSFOR Doctorate Program for the University of Lisbon-Higher Institute of Agronomy (ISA) with the title "Sacred Natural Places in the Tropical Forest, case study saltlicks in territories of indigenous communities" Tikuna and Uitoto (Colombia Amazon Trapeze).

${ }^{2}$ Legal and sociopolitical institution of a special nature, made up of one or more indigenous communities. With a collective property title enjoys the guarantees of private property, owns its territory and is governed, for the management of this and its internal life, by an autonomous organization protected by the indigenous jurisdiction and its own normative system. (Article 21, decree 2164 of 1995).

${ }^{3}$ In the text SMA is San Martin de Amacayacu.
} 
high biodiversity and richness indices. More than 130 species of trees and palms were identified in 90 genres and 30 botanic families. The families in the saltlicks samples with more number of trees or palms are Fabaceae, Arecaceae and Lecythidaceae. In the 6 saltlicks of SMA, 28 families with 59 genres were identified. The families with more individuals are Arecaceae, Fabaceae and Myristicaceae. In the 5 saltlicks of Los Kilometros, 30 families with 67 genres were identified. The families with more number of trees are Arecaceae, Fabaceae and Lecythidaceae. This information contributes to the knowledge of the saltlicks forest and helps the recognition and conservation of their flora.

\section{Subject Areas}

Environmental Sciences

\section{Keywords}

Trees Species, Saltlicks, Amazon Rainforest, Tikuna and Uitoto Ethnic Groups, Biodiversity, Composition, Colombia

\section{Resumen}

Para las etnias indígenas Tikuna y Uitoto, los salados son espacios naturales sagrados ubicados dentro de la Selva Amazónica. Su percepción, conocimiento, gestión y manejo espiritual ayuda a la conservación de más de 130 especies de flora identificadas en inventarios realizados en los salados.

El objetivo de este estudio fue analizar la composición y biodiversidad de la comunidad forestal en una muestra de 11 salados (6 salados en el resguardo TICOYA sector de San Martin de Amacayacu-etnia Tikuna, y 5 salados en el resguardo RITU sector los Kilometros, etnia Uitoto), reconocer los géneros (o especies hasta donde fue posible) y familias botánicas frecuentes. La información necesaria se obtuvo a través del trabajo de campo con inventarios realizados por medio de transectos de $4 \times 50 \mathrm{mts}$ en los años 2015, 2016 y 2017, con la ayuda de conocedores de flora de ambas comunidades.

Se concluye que la muestra de salados presenta índices de biodiversidad y riqueza altos. Se identificaron más de 130 especies de árboles y palmas en 90 géneros y 30 familiasbotanicas. Las familias con mayor número de individuos identificados son Arecaceae, Fabaceae, y Lecythidaceae.

En los 6 salados de SMA, se identificaron 28 familias con 59 géneros. Las familias con mayor número de individuos son familias Arecaceae, Fabaceae y Myristicaceae. En los 5 salados del sector los Kilometros, se identificaron 30 familias con 67 géneros. Las familias con mayor número de individuos son Arecaceae, Fabaceaey Lecythidaceae.

Esta información contribuye al conocimiento de la flora arbórea de los salados y ayuda al reconocimiento y conservación de sus comunidades de flora.

Palabras clave. Salados, árboles, especies, amazonas colombiano, etnias Tiku- 
na y Uitoto, biodiversidad, composición.

\section{Introduction}

According to [1] [2] and [3] one of the most important ways of conservation based on culture has been the identification and protection of sacred natural sites (SNS), which frequently have a valuable biodiversity; as well as these sacred natural places protect key ecosystems and heritage landscapes. Indigenous local and traditional cultures, with their respective worldviews, created protected areas before the beginning of Yellowstone National Park, which turned out to be the model used for the current legislation, policy and practices for protected areas. Sacred Natural Sites are therefore, the oldest protected areas on the planet.

SNS, are water or land areas with a special spiritual significance for native people and communities. These SNS can be perceived in a variety of scales. It can be a single tree or a rock formation and extend to an entire forest and mountain. In some cases whole landscapes are considered by one community or by several, as being sacred, containing within even more sacred centers. as informed [1] and [3] and Suchis the case of the Sierra Nevada de Santa Marta, the territory of the Yurupary Jaguars and the Sibundoy Valley in Colombia [4] [5] [6].

For many indigenous communities in Colombia, SNS are areas where nature connects with the greater consciousness and universe, where the collective or individual memories are reunited in meaningful ways. SNS can be home of deities, natural spirits and ancestors [7]. They are important sites of reference for the cultural identity of a clan, a tribe or a community. See too [8] and [9]. These places are marked in the topography creating territorial references, which in the Amazonas context are identified as saltlicks, cananguchales, morichales, varillales, hills, rivers, lakes, lagoons, waterfalls. As confirmed by [10] [11].

Saltlicks are part of sacred places or places with spiritual owner, appointment, history or special. These Spiritual Owners personify all the knowledge that allows the harmonious management of the ecosystem (ecosophy). As discussed in [12] and [13]. For Uitotos and Tikuna, saltlicks are the Malokas of the Jungle Owners, who are non-human beings with whom the Chaman negotiates the access to natural resources, food disease healing and ritual elaboration. See too [14] and [11]. The spiritual management of the saltlicks allows the regulation and balance the use of this biocultural heritage. See Figure 1.

For the western culture, saltlicks are biotopes, characterized by soils with high contents of minerals, in the form of salts and other minerals that are used directly by animals [15] [16]. The strongest influence on their formation is topography, as a conditioning agent as well as the parent material, as a factor that gives the chemical characteristics to these sites. The saltlicks can have between $30 \mathrm{~m}^{2}$ and 10,000 $\mathrm{m}^{2}$, and are used by animals (especially herbivores) to lick salt in dry times, to supply some mineral deficiencies that their normal diet does not include, or to attend a great demand of nutrients in some stages of their life as 


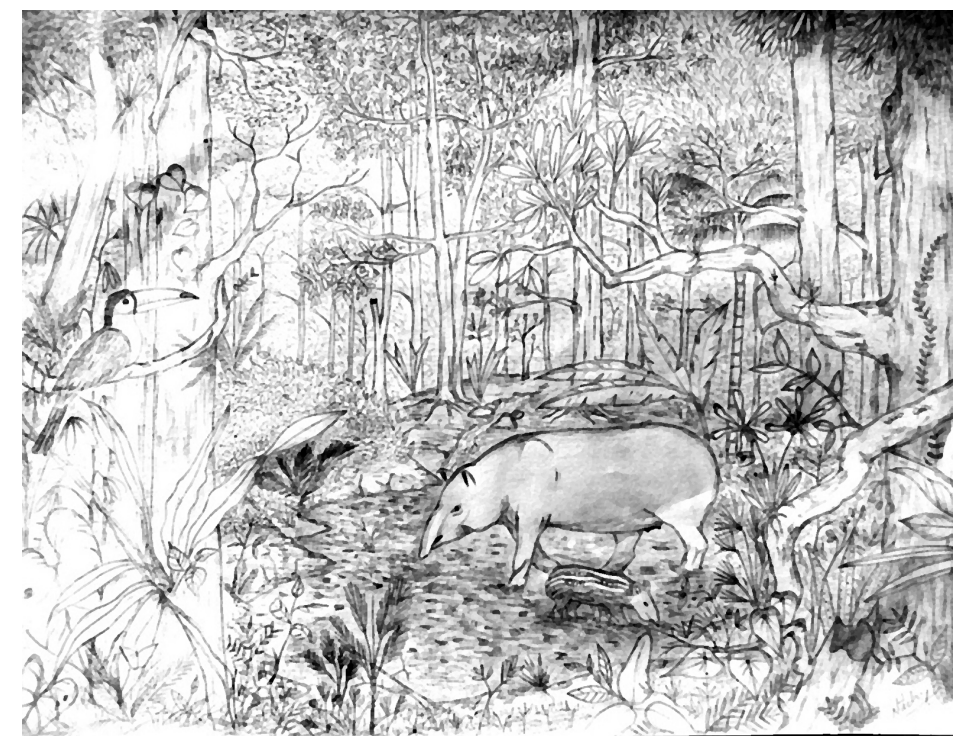

Figure 1. Saltlick drawing by Ignacio Sanchez (2017).

reproduction and [17] [18]. In the scientific literature saltlick are named as mineral licks, claylicks, natural licks, mineral springs, colpas, canama, salgados, salados.

Numerous sacred sites in Colombia are now in danger and suffer from a wide variety of pressures and threats: illegal logging, wildlife extractive industry operations, use and usurpation by outsiders; disrespectful tourism; poverty; marginality and high dynamics of their populations due to external pressures; degradation of surrounding environments; reduction of land and resource availability for indigenous communities [3] [7] [19] [20].

There are few studies that have approached the state of the structure, composition and richness of the forest saltlicks in the Colombia Amazonas Trapeze. The purpose of this article is to give an approximation of the structure, biodiversity and composition of a sample of saltlicks in two Resguardos in the Colombia Amazonas trapeze.

\section{Context and Methodology}

\subsection{Colombia Amazon Trapeze and Its Resguardos}

The Amazonas region in Colombia is political conformed by 6 departments with a total area of 40,494,267 Ha, and a population of approximately 1,000,000 inhabitants. This region represents nearly $10 \%$ of the Amazon basin, covering $43 \%$ of the Colombian territory, and has $80 \%$ of the area within the tropical humid forests (Bht). Its annual precipitation ranges between 2500 and 4000 cubic millimeters per year, with a $30^{\circ} \mathrm{C}$ average temperature and a relative humidity that rises up to $80 \%$. Along the year laps there are two periods of rain, an intense one in the months of January and February and one of less intensity during September and December [18] [21] [22].

The Amazonian trapeze is located within the Amazonas department (Colom- 
bia), it borders on the north with the Putumayo River, on the south by the Amazon River. To the east on the border line with Brazil from Tarapacá to Leticia, and to the West on the borderline with Peru from the Yaguas river in the Putumayo to the Atacuari River in the Amazon. In this area are located the Putumayo River with its main tributary, the Cotuhé, and the Amazon river with its tributaries Uassú, Atacuari, Loretoyacu and Amacayacu. The Amazon trapeze comprises the Municipalities of Leticia and Puerto Nariño. In terms of the native population, there are the indigenous communities of Tikuna, Cocama, Yagua, Uitoto, Muinane, Tanimuca who's people inhabit in several Resguardos [19] [21].

The Tikuna community extends from the Atacuari River between Colombia and Peru up to the Jutaí River in Brazil. In Colombia they occupy the entire Amazon trapeze with a population of 8.000 people. They share a "unique" language, with three dialects and live mainly on the banks of the Amazon River. They practice tomb and burning horticulture (chagras), fishing, hunting and tourism activities for income. Its Resguardos are: San Antonio de los Lagos, San Sebastián, El Vergel, Macedonia, Mocagua, San Martin de Amacayacu and Cothué-Putumayo, in the Department of Amazonas. More information consult [10] [18] [23]. See the location in Figure 2.

The Uitoto community (the Sons of Tabaco, coca and sweet yucca), live in the Colombo-Peruvian Amazon. The main settlements are located in the Igaraparaná and Carapararana rivers, in the Caquetá River middle courses, and in some Peruvian localities. At the end of the first third of the last century, no more than three thousand Uitotos survived to the ethnic elimination and genocidal action of rubber companies-domestic and foreign-forcing the displacement of many of them to the Amazonas trapeze. At present there are about 6000 Uitotos in Colombia [10] [24] [25]. In the Amazon trapeze, the Uitotos are located in the Kilometro 6 and 11 in the Leticia -Tarapacastreet (RITU), Arara, San Antonio de los Lagos and San Sebastián.

TICOYA Resguardo, has indigenous communities of the Tikuna, Cocama and Yagua tribes, making up a population of 56,201, distributed in 22 communities along the Amazon river and its tributaries the Atacuari, Boyahuasú, Loretoyacu
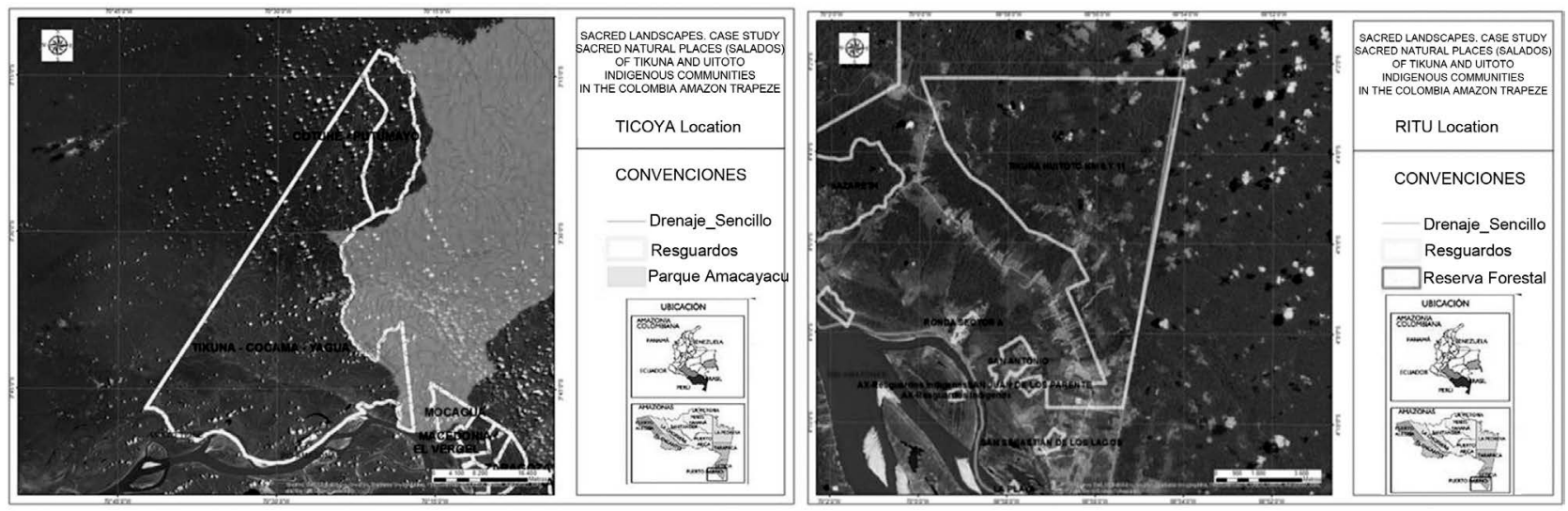

Figure 2. Indígenous resguardos. Source Google Earth, the authors. 
and Amacayacu [19] [26]. This Resguardo was created as a conservation area by decree No. 021 of March 13, 1990. The San Martin de Amacayacu community is formed mostly of Tikunas (600 people, according to CuracaMamerto Gregorio 2019).

RITU Resguardo or Los Kilometros, was constituted by resolution of INCORA $\mathrm{N}^{\circ} 005$ of 1986 with an extension of 7560 hectares, and is inhabited by more than 1563 indigenous. They are indigenous people who came from other parts of the Amazon, displaced by violence through Colombian history. The families are made up of two predominant ethnic groups, Tikuna and Uitoto ${ }^{4}$ [19] [27].

\subsection{Tracing and Inventory Sampling}

The procedure was developed in three stages. 1) Identification and analysis of relevant information about saltlicks and its flora composition and structure, assigning particular value to the information on the Tikuna and Uitoto life plans 5 . 2) Visits and recognition of 11 saltlicks in the years 2015, 2016, 2017, 2019 with the permission and the attendance of a Tikuna family in SMA, and Uitoto indigenous guides in Los Kilometros. See Table 1. The status and forest structure by inventories was made, and the current management of saltlicks were observed. 3) Analysis of biodiversity indicators, statistical analysis and conclusions.

The visit and identification of the 11 saltlicks was carried out with the accompaniment of indigenous knowledgeable locals (see Table 1). Along with them, was calculated the approximate area to establish transects of $(4 \times 50 \mathrm{~m})$ with a distance between each transect of at least 60 meters, the guides suggestions were accepted for the location of the transects and interior ways to transit into the saltlick, in order to respect the areas of more use of the local animals and the most susceptible areas to human presence as the licking areas. The approximate location of the saltlicks and some images of its forest component are shown in Figures 3-7.

This research procedure was circular and in permanent redesign due to the social, environmental and access conditions to these areas. The method proposed had to be adjusted according to the possibilities of accessibility to such places - the saltlicks, access conditions of the land, permissions granted, available time of the field guides, climatic state, economic conditions for the displacement and payment of guides.

21 transects were recorded along the SMA and 28 transects in the Kilometers see Table 2.

Trees $^{6}$ with diameters at breast height more or equal to $10 \mathrm{~cm}$ were characterized; species data (local name) and approximate total height were recorded. See Table 3.

Tree data with their respective identified species were analyzed using the

${ }^{4}$ For more information look https://www.youtube.com/watch?v=kBcauPW4rgI\&list=LLk4-VFCPgHn_fA7c1SCeF2 w\&index=7. ${ }^{5} \mathrm{https}: / /$ www.youtube.com/watch?v=5paJyhf_Flo\&index=6\&list=LLk4-VFCPgHn_fA7c1SCeF2w. ${ }^{6}$ In the text threes are the same of tree and palm species. 
Table 1. Guides and local experts collaborators for saltlicks identification, inventory and information collection. Source: the authors.

\begin{tabular}{|c|c|c|}
\hline Name & Place & Occupation \\
\hline $\begin{array}{l}\text { Humberto } \\
\text { Gregorio-Clan } \\
\text { Cascabel }\end{array}$ & $\begin{array}{c}\text { San Martin de } \\
\text { Amacayacu-TICOYA }\end{array}$ & $\begin{array}{l}\text { Hunter, knowledgeable of flora and } \\
\text { fauna, local guide, grandfather of } \\
\text { the knowledge council of the } \\
\text { Tikuna community }\end{array}$ \\
\hline $\begin{array}{l}\text { Robinson } \\
\text { Gregorio-Clan } \\
\text { Cascabel }\end{array}$ & $\begin{array}{c}\text { San Martin de } \\
\text { Amacayacu-TICOYA }\end{array}$ & $\begin{array}{l}\text { Guide and knowledgeable about } \\
\text { flora and fauna, fisherman and } \\
\text { local guide. Tikuna translator }\end{array}$ \\
\hline $\begin{array}{c}\text { José Gregorio-Clan } \\
\text { Cascabel }\end{array}$ & $\begin{array}{c}\text { San Martin de } \\
\text { Amacayacu-TICOYA }\end{array}$ & $\begin{array}{l}\text { Flora knowledge, fisherman and } \\
\text { community leader Tikuna }\end{array}$ \\
\hline $\begin{array}{l}\text { Mamerto Antonio } \\
\text { Gregorio-Clan Cascabel }\end{array}$ & $\begin{array}{c}\text { San Martin de } \\
\text { Amacayacu-TICOYA }\end{array}$ & $\begin{array}{l}\text { Curaca, leader, traslator and local } \\
\text { research Tikuna }\end{array}$ \\
\hline $\begin{array}{l}\text { Antonio Cayetano } \\
\text { Sánchez. }\end{array}$ & Los Kilómetros-RITU & $\begin{array}{l}\text { Malokero, grandfather of the } \\
\text { knowledge council of the Uitoto } \\
\text { community }\end{array}$ \\
\hline Nicanor Morales & Los Kilometros-RITU & $\begin{array}{l}\text { Hunter, knowledgeable of flora and } \\
\text { fauna, local guide, grandfather of } \\
\text { the knowledge council of the } \\
\text { Uitoto community }\end{array}$ \\
\hline $\begin{array}{l}\text { Walter Torres } \\
\text { Fariratofe }\end{array}$ & Los kilómetros_RITU & $\begin{array}{l}\text { Hunter, knowledgeable of flora and } \\
\text { fauna, local guide, Uitoto }\end{array}$ \\
\hline Jesús Vargas & Los kilómetros-RITU & $\begin{array}{l}\text { Hunter, knowledgeable of flora and } \\
\text { fauna, local guide, Uitoto }\end{array}$ \\
\hline Jesus Negedeka & Los Kilómetros-RITU & $\begin{array}{l}\text { Hunter, knowledgeable of flora } \\
\text { and fauna, local guide, } \\
\text { Muinanecommunity }\end{array}$ \\
\hline Celimo Negedeka & Los Kilómetros-RITU & $\begin{array}{l}\text { Hunter, knowledgeable of flora } \\
\text { and fauna, local guide, Muinane } \\
\text { community }\end{array}$ \\
\hline Ignacio Sánchez & Los kilómetros-RITU & $\begin{array}{l}\text { Forest engineer student } \\
\text { Universidad Distrital Francisco } \\
\text { Jose de Caldas, Uitoto indigenous } \\
\text { research. }\end{array}$ \\
\hline
\end{tabular}

Table 2. Forest base information of saltlicks. Source: the authors.

\begin{tabular}{cccc}
\hline Resguardo & saltlicks & Sampling area in $\mathrm{m}^{2}$ & Number of transects $(4 \times 50 \mathrm{mt})$ \\
\hline \multirow{3}{*}{ SMA- TICOYA } & Patura & 1000 & 5 \\
& Venado & 1000 & 5 \\
& Huito & 600 & 3 \\
& Maloka & 800 & 4 \\
& Piedra & 800 & 4 \\
& Aramacia & 600 & 3 \\
Los & Caimo & 1600 & 8 \\
Kilometros-RITU & Pequeño & 600 & 3 \\
& Kayetano & 2000 & 10 \\
& Jonhy & 600 & 3 \\
\hline
\end{tabular}


Table 3. Heights and diameters trees classification. Source: the authors.

\begin{tabular}{cc}
\hline High in the vertical strata & Diameter $^{7}$ rangers \\
\hline $\mathrm{H} 1<2 \mathrm{~m}$ & DAP A $(10-30 \mathrm{cms})$ \\
$\mathrm{H} 2(2-10 \mathrm{~m})$ & DAP B $(30-60 \mathrm{cms})$ \\
$\mathrm{H} 3(10-20 \mathrm{~m})$ & DAP C $>60 \mathrm{cms}$ \\
$\mathrm{H} 4(20-30 \mathrm{~m})$ & \\
$\mathrm{H} 5>30 \mathrm{~m}$ & \\
\hline
\end{tabular}

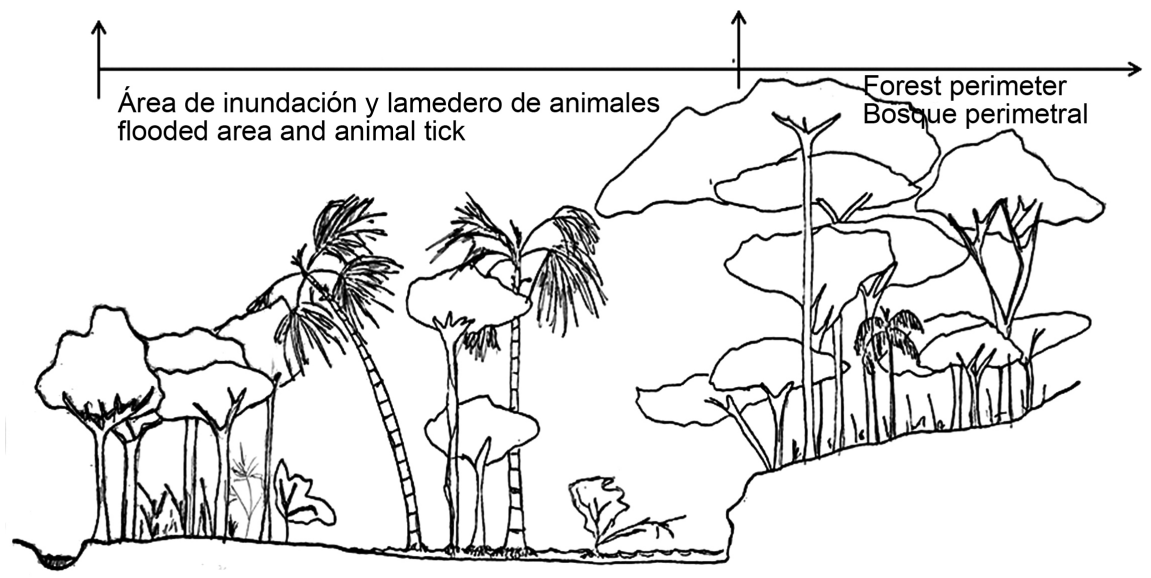

Figure 3. Drawing of a saltlick adapted from [28]. Source: the authors.

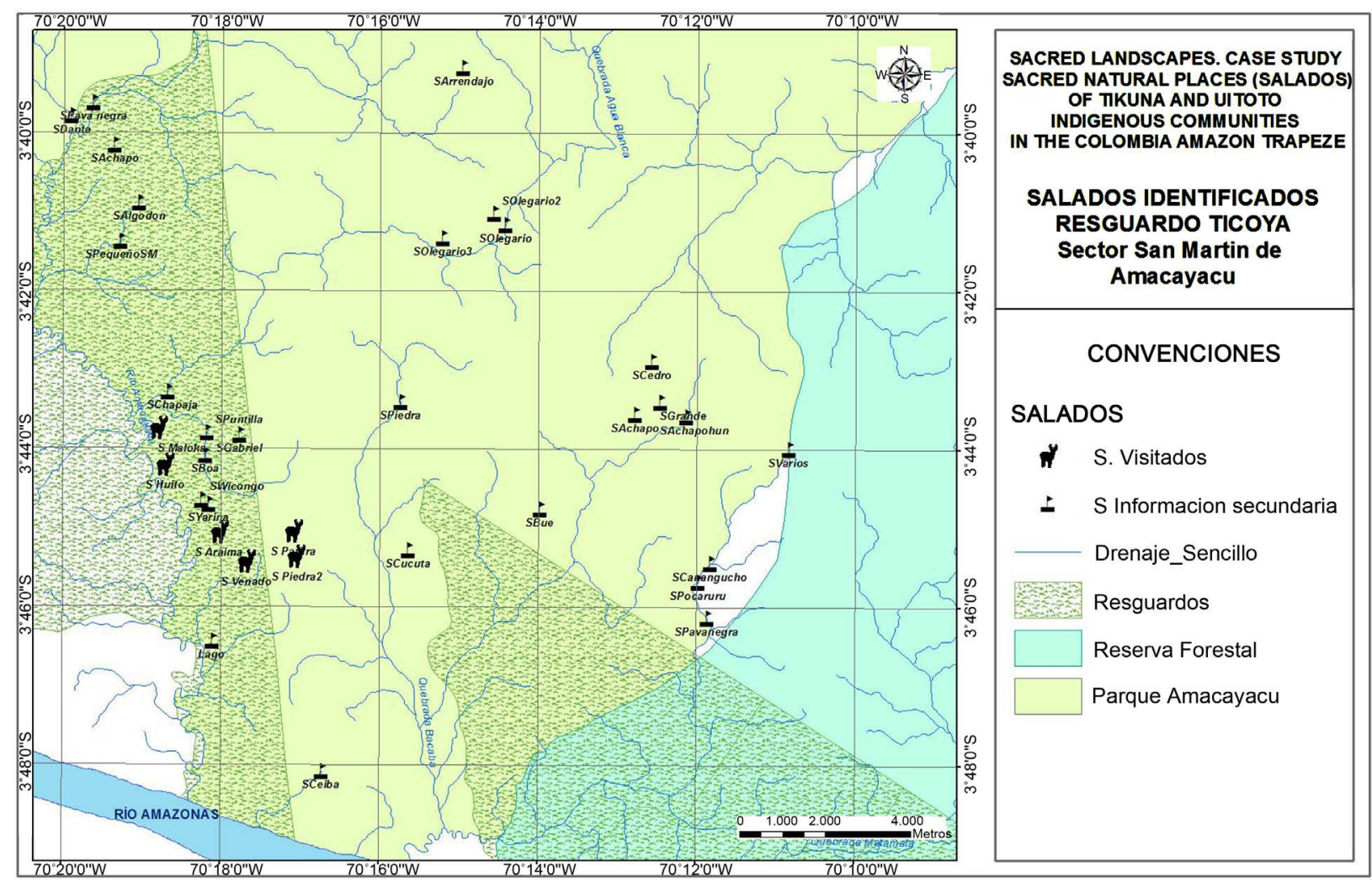

Figure 4. Location of the saltlicks visited near of SMA and reported by secondary reports. Source: the authors.

${ }^{7}$ Measured diameter of the trunk at 1.3 meters above the ground. 

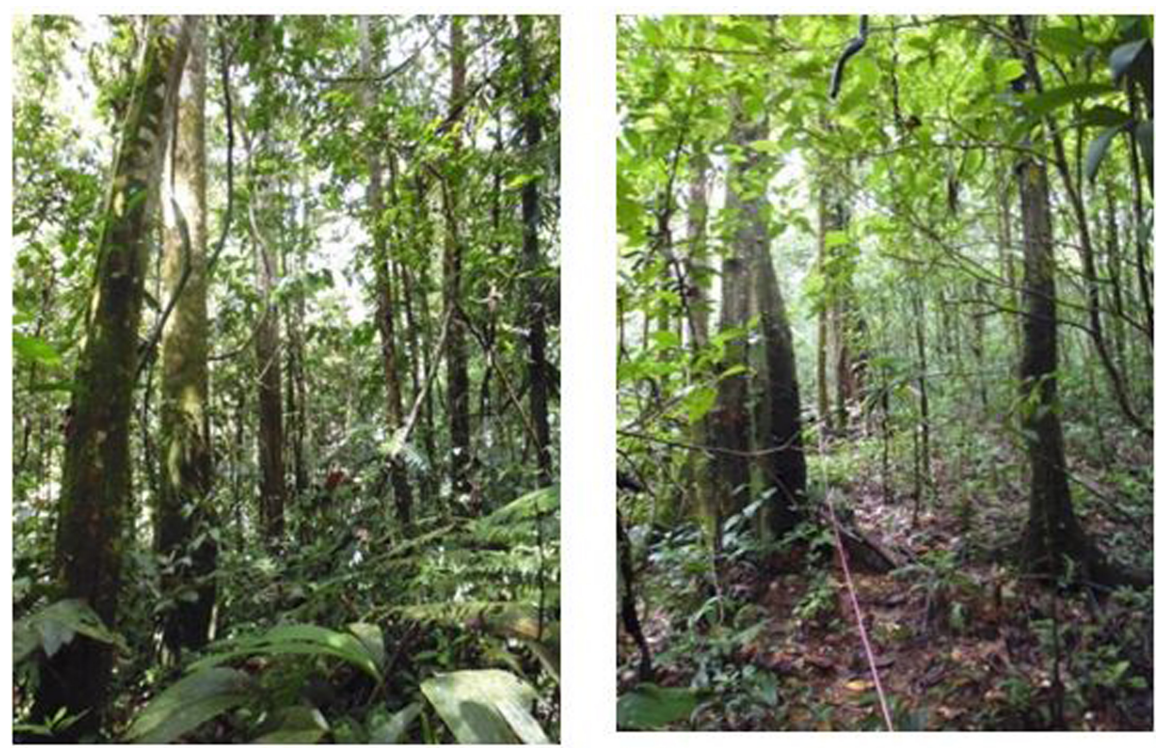

Figure 5. Forest cover in the saltlicks of SMA. Source: the authors.

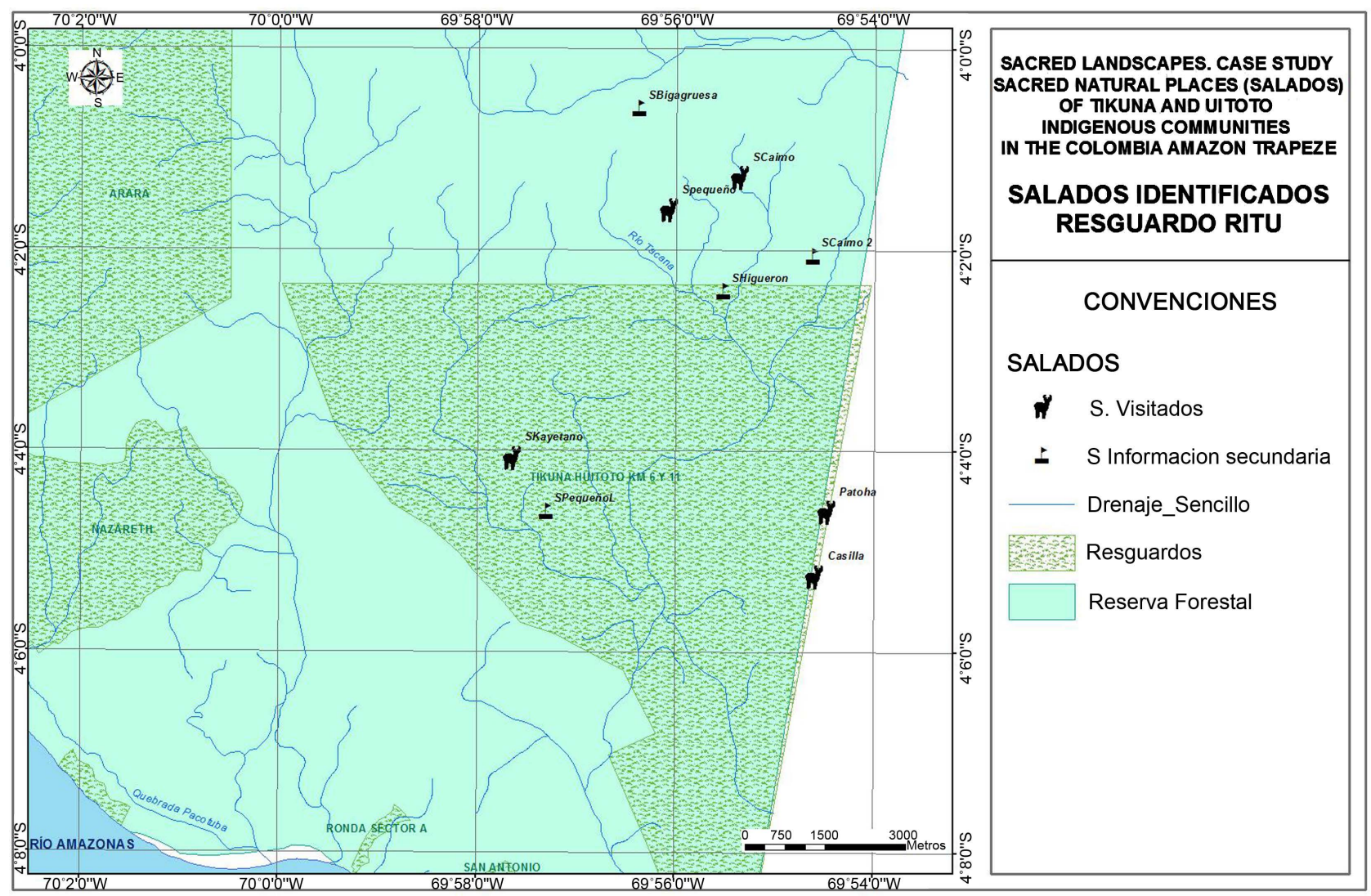

Figure 6. Location of the saltlicks visited near of Los Kilometros village. Source: the authors.

Diversity, Dominance, Equity and Wealth indices described in [29], in order to determine the differences between the saltlicks of each Resguardo. The indices used were:

1) Diversity Shanon-Weaver (1949) index 

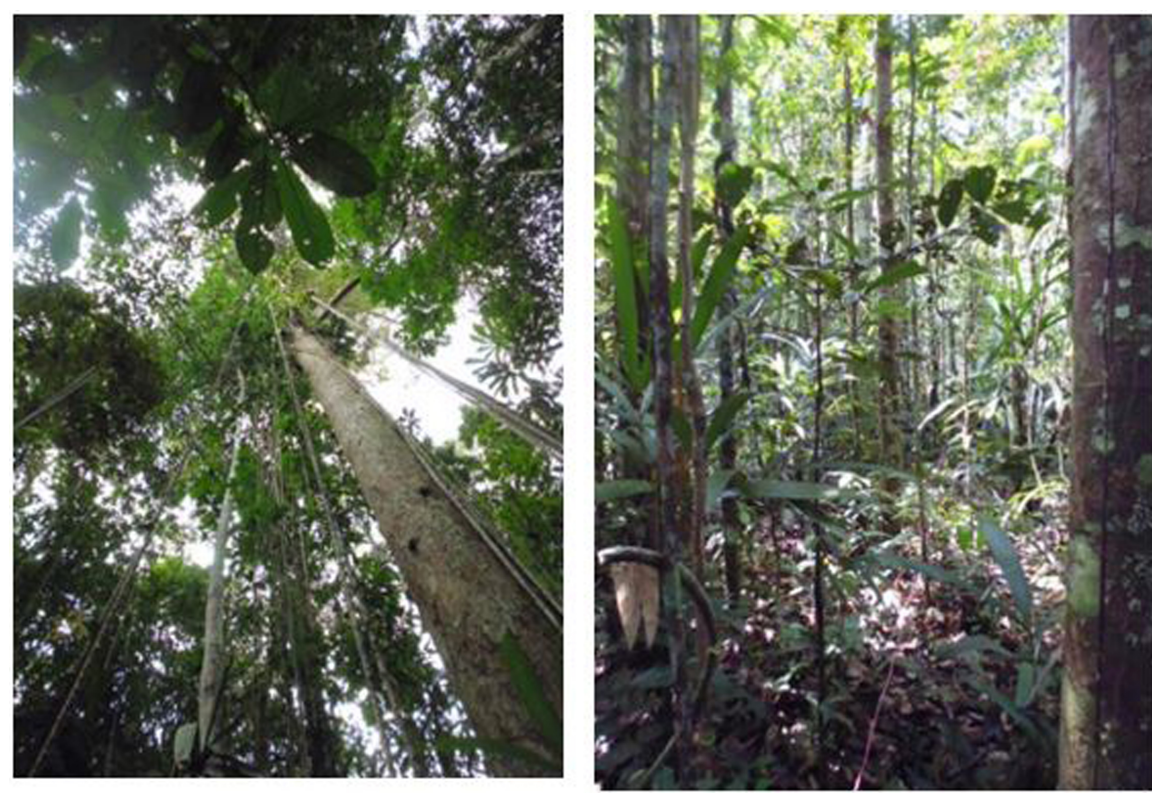

Figure 7. Forest cover in the saltlicks of Los Kilometros. Source the authors.

$$
H=-\sum \frac{n_{i}}{N} * \ln \left(\frac{n_{i}}{N}\right)
$$

$H$ : is Shannon-Weaver's diversity index; $n_{i}$ is the number of individuals of each species; $N$ : is the total number of individuals; ln: it is the natural logarithm.

Values between 0 and 1.0 of $\mathrm{H}$ indicate slightly biodiverse environments, between 1.0 and 3.0 correspond to moderately biodiverse environments and, of 3.0 or onwards, environments of good biodiversity [29].

2) Simpson's dominance index (1949)

$$
D=\frac{\sum n_{i}\left(n_{i}-1\right)}{N(N-1)}
$$

$D$ : is Simpson's dominance index; $n_{i}$ is the number of individuals of each species; $N$ : is the total number of individuals

The values for this index are between 0 and 1.0. As dominance increases, diversity decreases.

3) Equity index of Pielou (1966)

$$
J=\frac{H}{\ln (S)}
$$

J: is the equity index of Pielou; $H$ : it's the Shanon-Weaver diversity index; $S$ : is the number of species; ln: is the natural logarithm

This index is between 0 and 1.0, where the value of 0 represents the minimum equity and 1.0, the maximum equity.

4) Margalef s richness index (1968)

$$
R=\frac{S}{\ln (N)}
$$


$R$ : is Margalef's richness index; $S$ : is the number of species; $N$ : is the total number of individuals; $\ln$ : is the natural logarithm.

If the Margalef index is less than 2.0, is low richness in the environment, if it is between 2.0 and 5.0, there is moderate richness, if it is greater than 5.0, there is great richness in the ecosystem [29].

\subsection{Biodiversity Statistical Analysis}

Using the SPSS statistical program, the data was analyzed in order to recognize if significant differences between the compositions of the saltlicks in both Resguardos existed. In total 756 trees were analyzed in 143 taxonomic units at the level of genre and species (when the tree was fully identified).

The univariate analysis tool with the fixed variable Resguardos and saltlick name, and the area of inventory as a covariate, were used to analyze if the dependent variables such as number, species, family, genre, diameter (DAP) and height stratum $(\mathrm{H})$ have significant relationships between them.

\section{Results}

\subsection{Saltlicks for Tikuna and Uitoto Communities}

The saltlick is a very special place in the jungle to see animals [30]. Under the perception of Tikuna and Uitoto this places are the doors of the Malokas for the animal's parties (where the animals transformed into men take Masato and dance). The saltlicks are social spaces for humans and non-humans animal (personal communication Gregorio, Morales and Negedeka families, 2015, 2016, 2017).

Saltlicks are composed of two areas ${ }^{8}$ : one area remains most of the time flooded with species of flora adapted to their salt condition; this is where the traces of numerous species of animals are in evidence. The other area corresponds to the forest of the mainland. Each saltlick has a dominant species of animal; the area that corresponds to the perimeter forest for each saltlick can oscillate between 60 and 600 meters from the edge of the water or wet zone. This forest area is delimited for protection purposes by the indigenous community. In both areas extractive activity of vegetation and hunted are not allowed.

For Tikuna and Uitoto the saltlicks are considered prohibited and/or enchanted spaces. Inside them it is prohibited to hunt, collect fruits, eliminate associated flora, cut trees, and change the land use. They must be entered with the permission of their respective owner. Table 4 gives a definition of these spaces along with others considered sacred for both ethnic groups.

\subsection{Saltlicks Forest}

In the visits made to the 11 Saltlicks in both Resguardos, more than 120 trees species were identified (see Table 5). It was possible to observe that more number of species and trees exist in Venado and Maloka saltlicks (SMA), and ${ }^{8}$ See Figure 3. 
Table 4. Typology of some natural places of importance for the Uitoto and Tikuna indigenous communities. Source [21] corroborated in personal communication with the families Negedeka, Morales and Gregorio $(2015,2016,2017)$.

\begin{tabular}{|c|c|c|c|}
\hline $\begin{array}{l}\text { Natural } \\
\text { Places }\end{array}$ & Concept & Location (Uitoto) & Location (Tikuna) \\
\hline 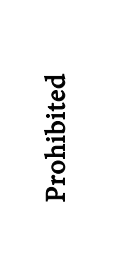 & $\begin{array}{l}\text { Reserved areas. It is not } \\
\text { allowed hunting, } \\
\text { fishing, collecting, } \\
\text { sowing, clearance, } \\
\text { deforestation, wood } \\
\text { cutting, these sites were } \\
\text { inhabited by creators. }\end{array}$ & $\begin{array}{l}\text { Cananguchales, streams, } \\
\text { lakes, ponds, mountains, } \\
\text { saltlicks, origin sites } \\
\text { (chorera place), } \\
\text { cemeteries, hills. }\end{array}$ & $\begin{array}{l}\text { Cananguchales, streams, } \\
\text { lakes (Chica, largo, Tigre, } \\
\text { Julio, Sabalo), mountains, } \\
\text { saltlicks, origin sites (Eware } \\
\text { river), cemeteries, hills (Bue, } \\
\text { Kwapu, Yoyoene, Twirupw). }\end{array}$ \\
\hline 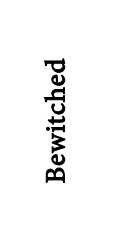 & $\begin{array}{l}\text { It is not allowed to enter } \\
\text { without the permission } \\
\text { of its spiritual owners, } \\
\text { through clean, } \\
\text { purification and } \\
\text { harmonization rituals. }\end{array}$ & $\begin{array}{l}\text { Cerro del Diablo, } \\
\text { Chorro Nofko, } \\
\text { cananguchales, streams, } \\
\text { rivers, huecadas, lakes, } \\
\text { ponds, saltlicks. }\end{array}$ & $\begin{array}{l}\text { Tarapatolake, Amacayacu } \\
\text { and Amazonas river, lagarto } \\
\text { cocha stream, Mkarepu } \\
\text { loma, Bougunelagoon, } \\
\text { Moruapu aguajal. }\end{array}$ \\
\hline
\end{tabular}

Table 5. Forest saltlicks basic information of SMA and Los Kilometros source the authors.

\begin{tabular}{ccccc}
\hline Resguardo & Saltlicks name & Tree number & Species number Families number \\
\hline & Patura & 63 & 31 & 18 \\
& Venado & 75 & 37 & 21 \\
SMA-TICOYA & Huito & 41 & 22 & 17 \\
& Maloka & 57 & 29 & 16 \\
& Piedra & 46 & 28 & 16 \\
& Aramacia & 54 & 26 & 17 \\
& Kaimo & 120 & 40 & 23 \\
& Pequeño & 52 & 21 & 12 \\
Los Kilometros-RITU & Kayetano & 176 & 68 & 28 \\
& Jonhy & 29 & 18 & 11 \\
\hline
\end{tabular}

Kayetano and Kaimo saltlicks (Los Kilometros).

144 species $^{9}$ of trees were identified in six saltlicks in SMA, and 130 species of trees in the five saltlicks of Los Kilómetros. All the saltlicks have more than 60 genres and 21 families.

Graph 1 shows a Family summary (botanic families most frequently identified in the saltlicks visited). The frequent families are Fabaceae, Arecaceae and Lecythidacea.

As a complement to Graph 1, in the saltlicks of SMA, 28 families with 59 genres were identified. The 3 families with more individuals are Arecaceae, Fabaceae and Myristicaceae. In saltlicks of Los Kilometros, 30 families with 67 genres ${ }^{9}$ Some of them only with genre. 


\section{Saltlicks Families}

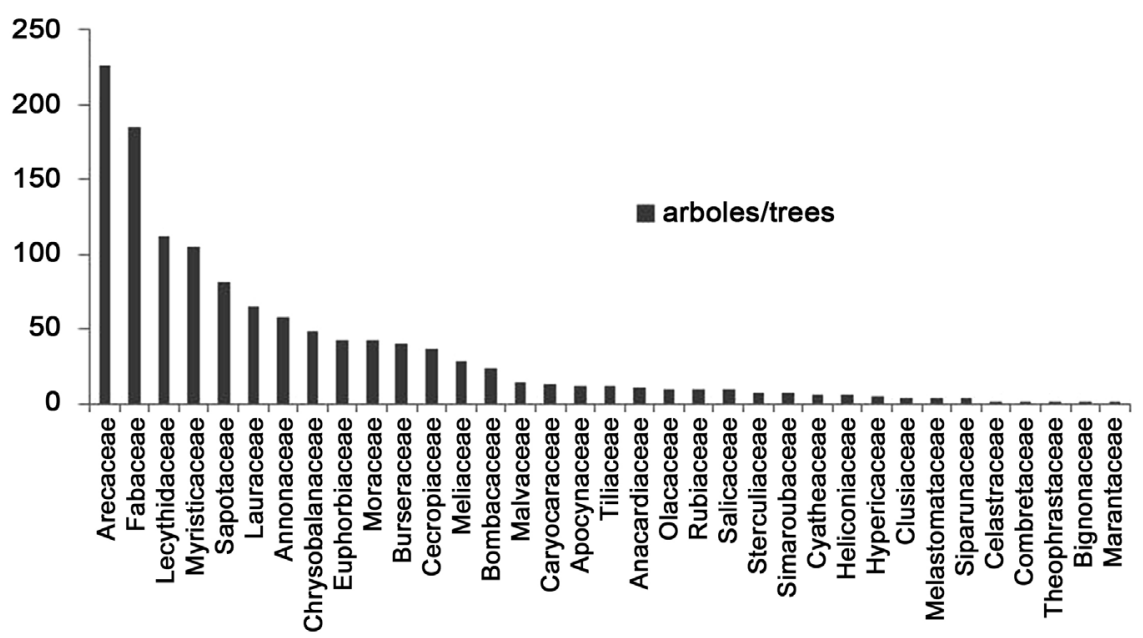

Graph 1. Botanical families distribution by number of trees in the saltlicks sample. Source: The authors.

were identified. The 3 families with more number of individuals are Arecaceae, Fabaceae and Lecythidaceae.

Table 6 and, Figure 8 and Figure 9, show a summary of the botanical genres in saltlicks that have more than one tree in each saltlick and that are present in four or more saltlicks in each Resguardo. Dominating genre was not found in the inventoried saltlicks.

The Eschweilera genre is common in $90 \%$ of all the saltlicks in both Resguardos, representing between $10 \%$ and $12 \%$ of saltlicks trees. The Astrocaryum, Inga and Iryantheragenres, are common in $80 \%$ of the saltlicks in SMA. Astrocaryum is found in different percentages, the highest percentage of these palms is in Huito saltlick with $21 \%$.

The Inga genre and Virolagenre are represented in approximately $10 \%-15 \%$ of the trees in the saltlicks of SMA. See de following graphics in Figure 8.

In the meantime, Licania and Pouteria genres are frequent in $80 \%$ of the saltlicks in Los Kilometros, but they do not represent more than $10 \%$ of the trees in these saltlicks (Figure 9).

\section{Forest Structure}

In both Resguardos, the distribution of the trees according to their diameter, concentrate in the DAP A and DAP B diametric classes ${ }^{10}$.

In SMA saltlicks, the trees that are in more proportion in DAP A class, were identified in Patura, Venado, Huito and Maloka saltlicks. In DAP B diametric class Piedra and Aramacia saltlicks. In Los Kilometros, the trees that are more in proportion to the DAP A diametric class, were identified in Pequeño, Johny and Patoha saltlicks, and the diametric class DAP B in Caimo and Kayetano saltlicks. See Graph 2 that illustrates the distribution of the diameters for both Resguardos.

${ }^{10}$ See Table 3. 
Table 6. Frequent botanical genres in saltlicks. Source: the authors.

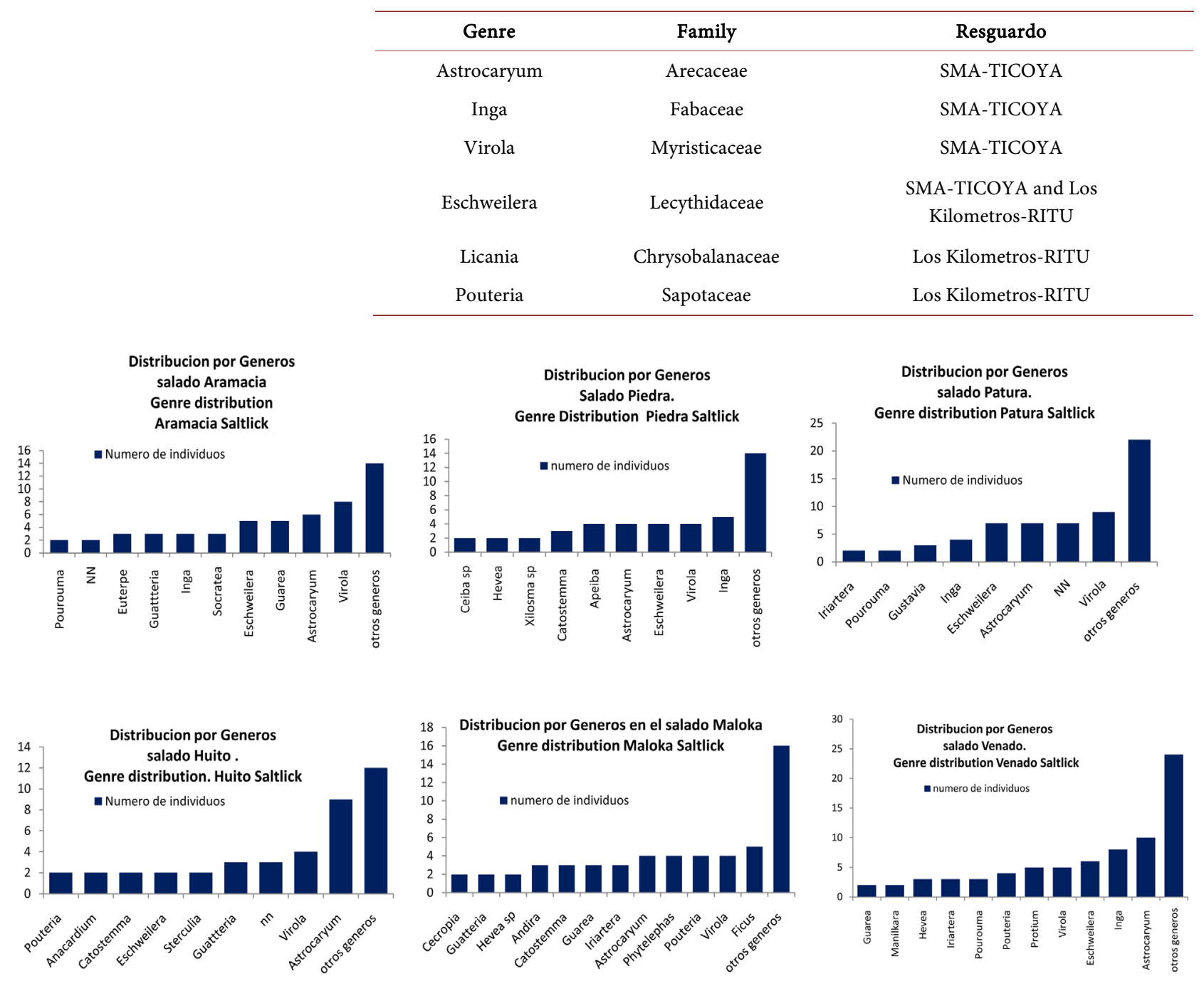

Figure 8. Botanical genre distribution in each saltlick of SMA-TICOYA. Source: the authors.

For the distribution of tree heights by strata, they occur in more number between strata $\mathrm{H} 3$ and $\mathrm{H} 4$ (see Graph 3).

In SMA, the trees heights are concentrated in stratum $\mathrm{H} 3$ in all the saltlicks. In Maloka saltlick has a few dominance in stratum H4. In Los Kilometros has concentrate of trees in stratum $\mathrm{H} 3$ in Pequeño, Jhony and Kayetano saltlicks. In stratum H4 in Kaimo and Patoha saltlicks.

In the saltlicks samples, the trees do not have big diameters, their heights are concentrated in the middle strata $\mathrm{H} 3$ with few trees in the upper strata ( $\mathrm{H} 4$ and H5). This is explained by the special conditions of humidity and salinity of saltlicks, which are reported by several authors. See too [16] [17] [28] [30]. In the statistical analyzes, the tree diameters and heights did not show significant differences between saltlicks of both resguardos.

The following figures show 3 saltlicks drawings in SMA-TICOYA and 3 saltlicks drawings in Los Kilometros-RITU, with the typical tree distribution in 

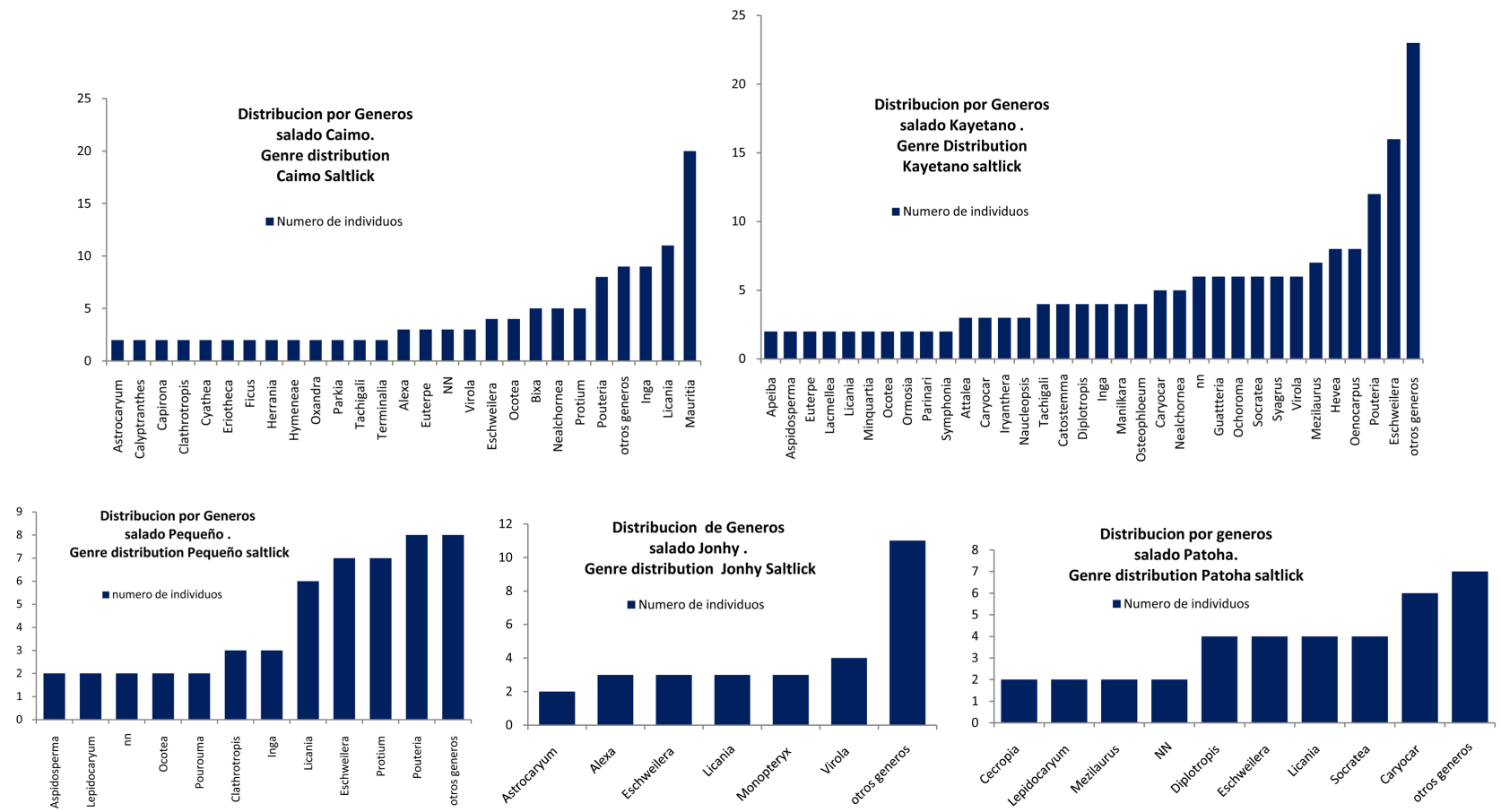

Figure 9. Botanical genre distribution in percentage in each saltlick of Los Kilometros-RITU. Source: the authors.
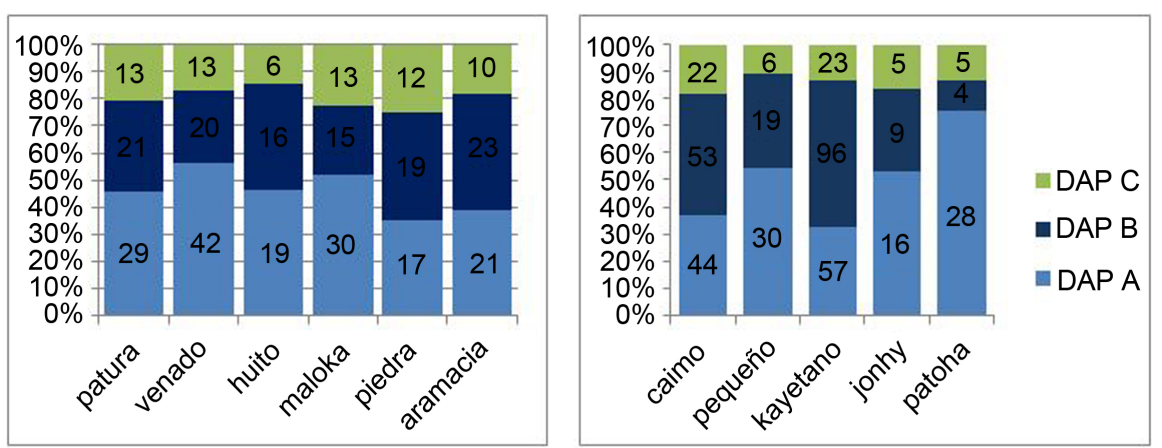

Graph 2. Saltlick tree diameters distribution for both Resguardos. Left SMA saltlicks, right Los Kilometros saltlicks. Source: the authors.
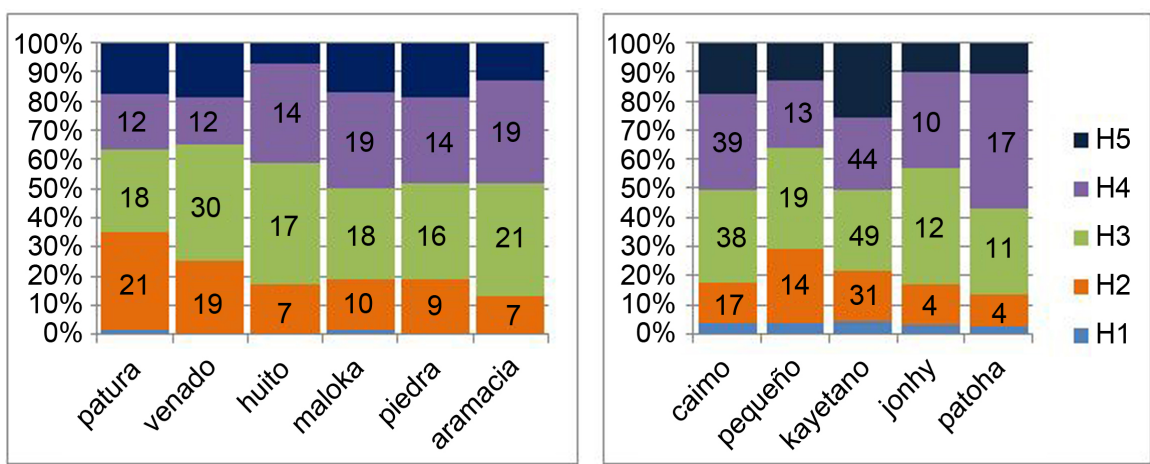

Graph 3. Saltlicks heights distribution under methodology parameters. Left SMA saltlicks, right Los Kilometros saltlicks. Source: the authors.

heights and species composition in a transect (Figures 10-15). 


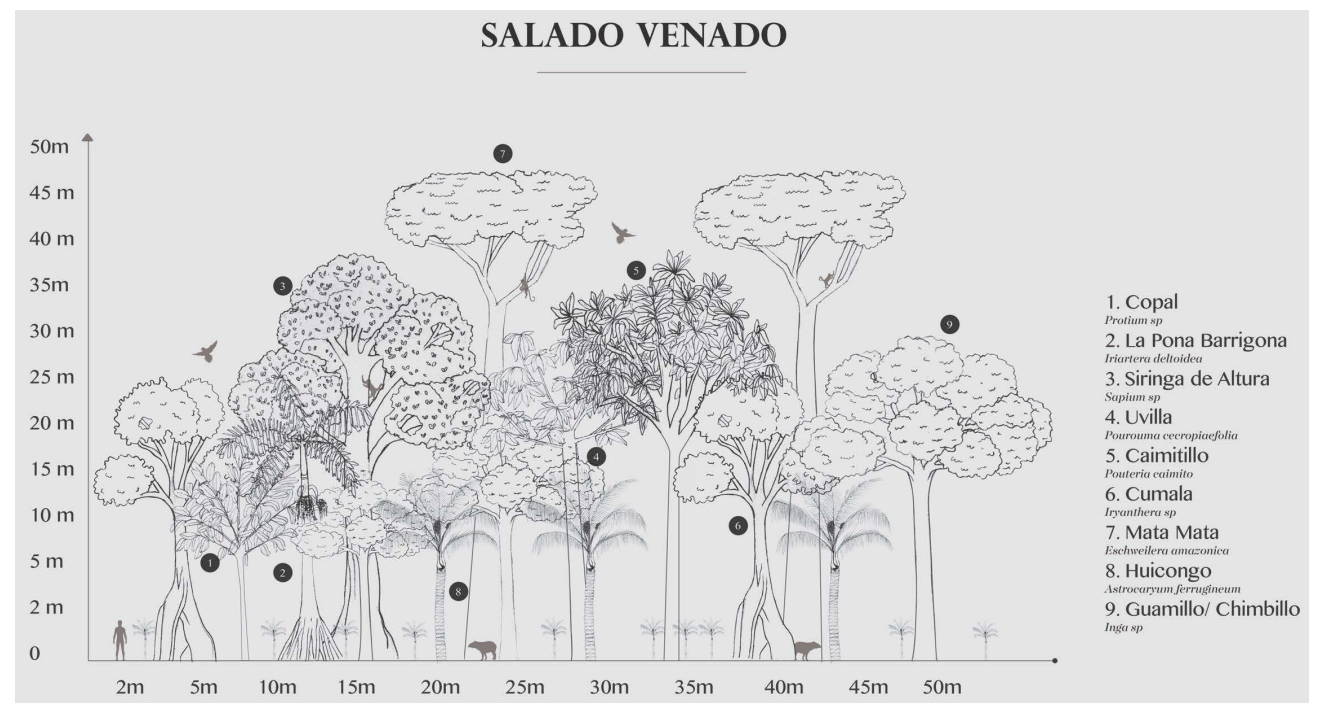

Figure 10. Venado saltlick in SMA. Source: the authors.

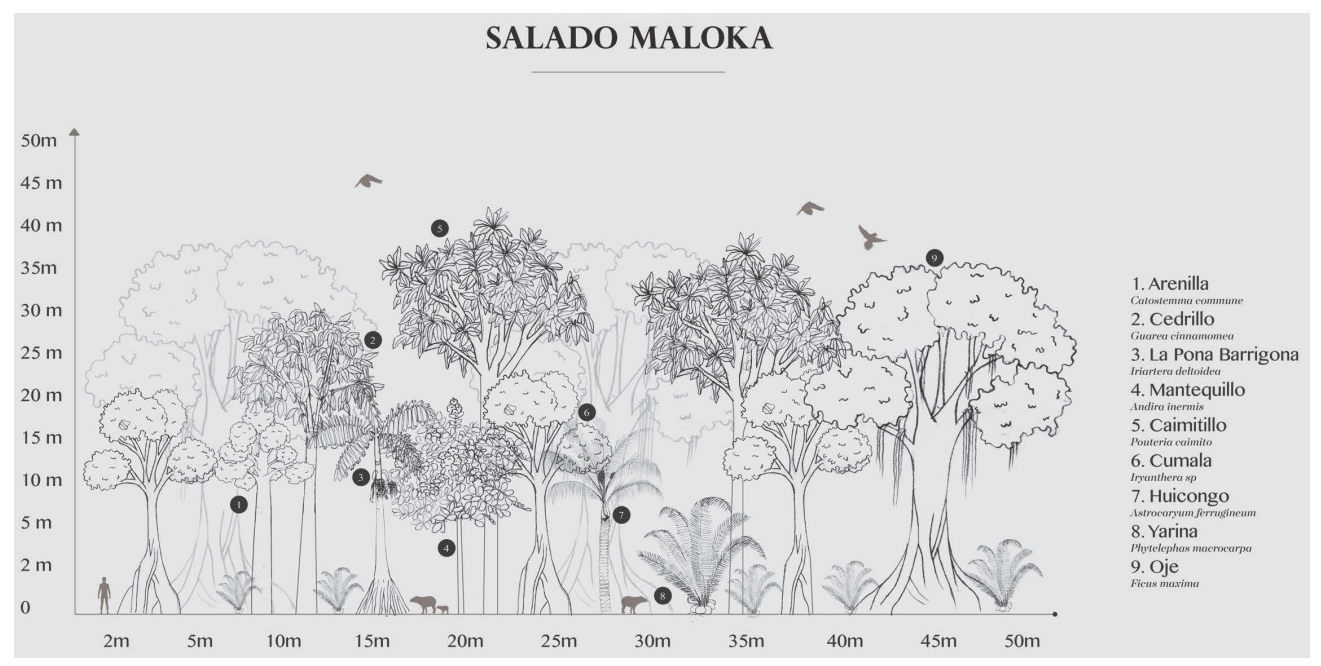

Figure 11. Maloka saltlick in SMA. Source: the authors.

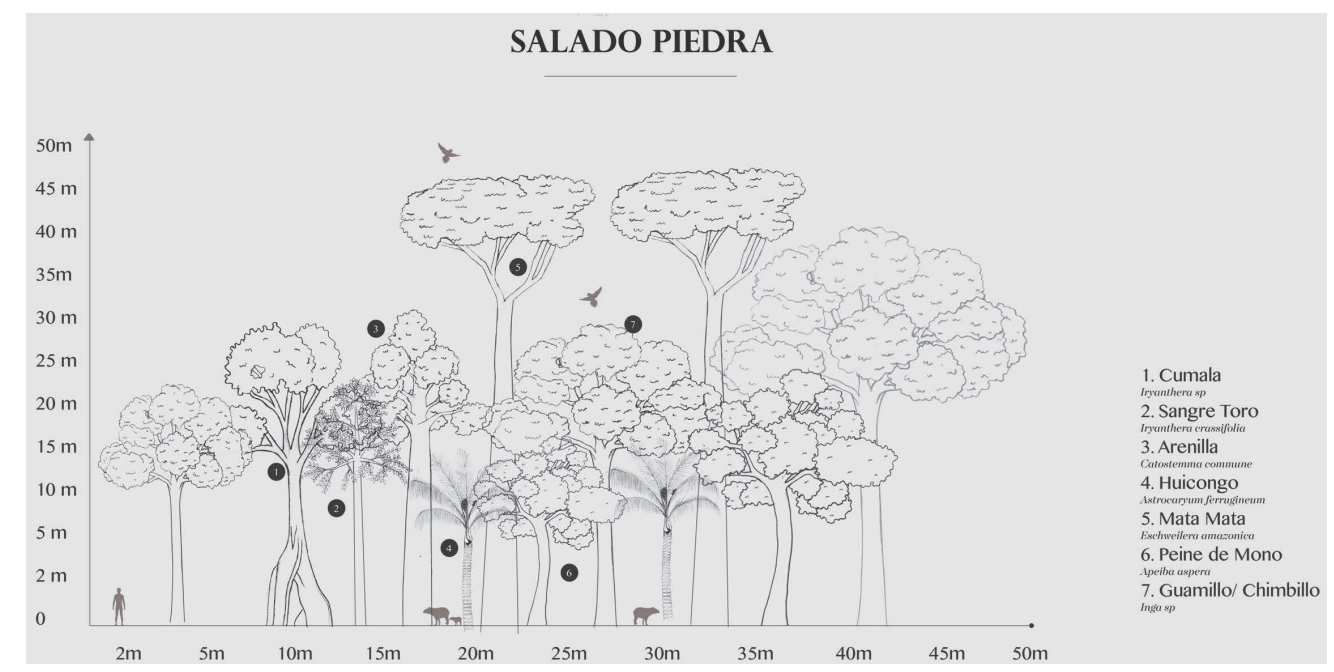

Figure 12. Piedra saltlick in SMA. Source: the authors. 


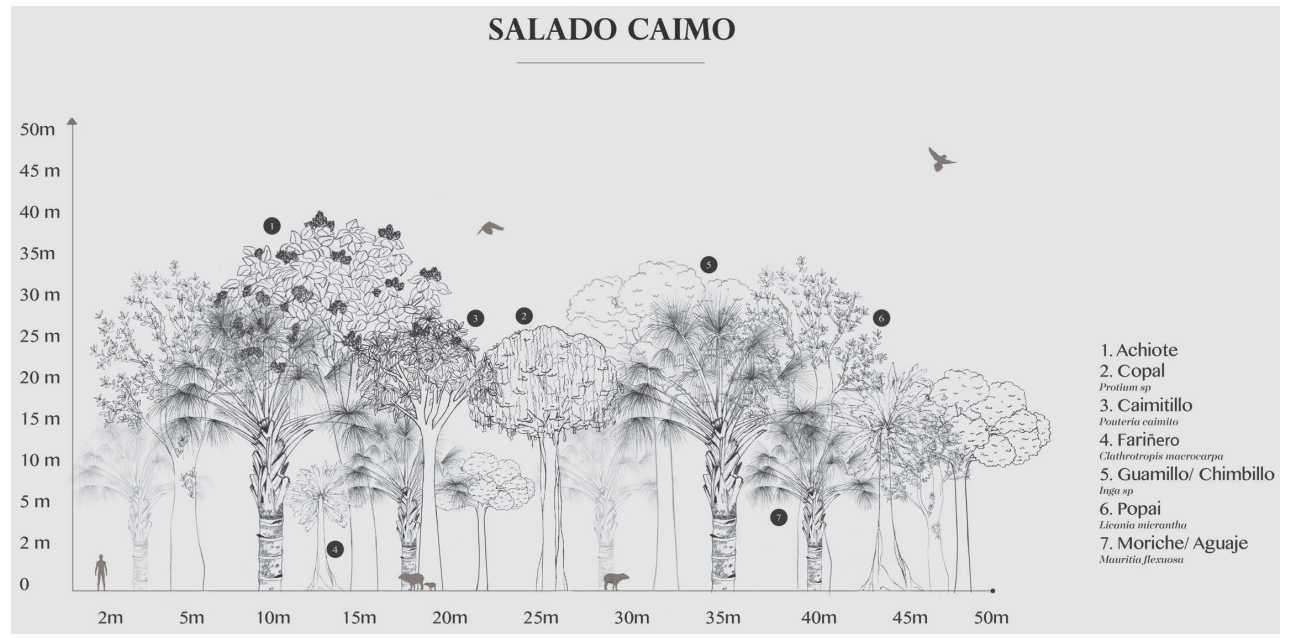

Figure 13. Caimo saltlick in Los Kilometros-RITU. Source: the authors.

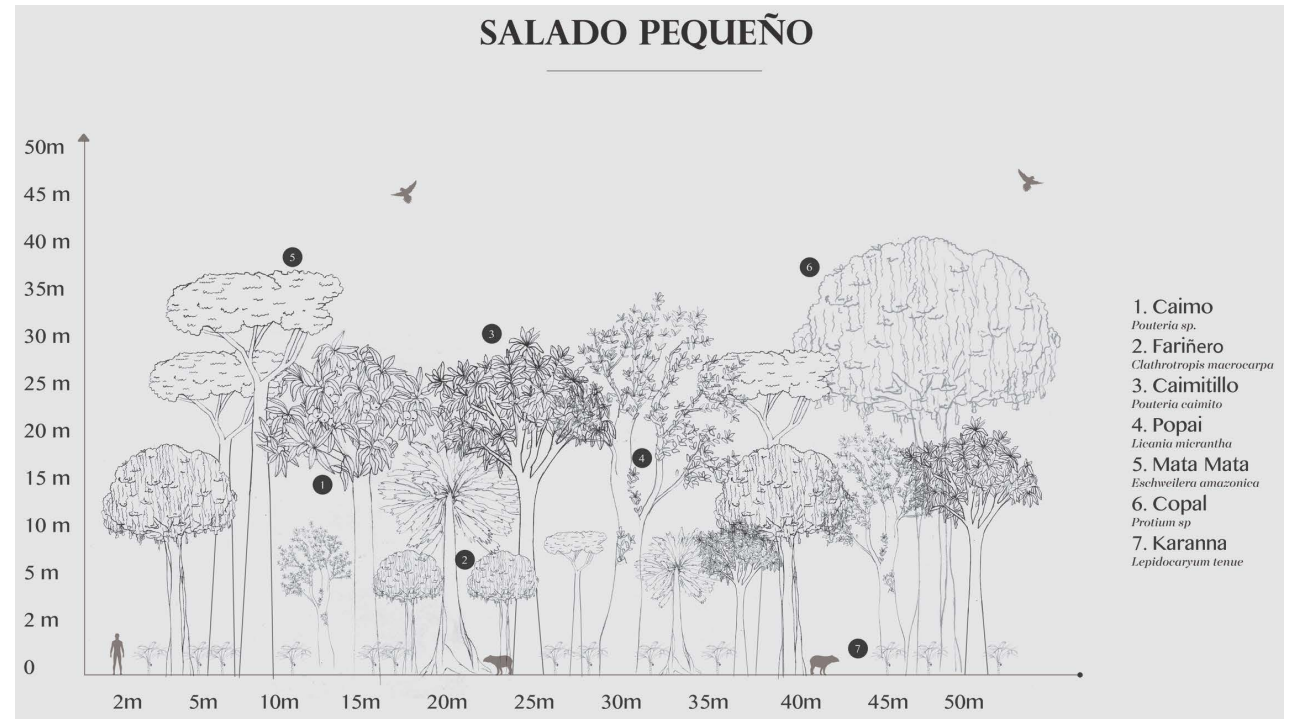

Figure 14. Pequeño saltlick in Los Kilometros-RITU. Source: the authors.

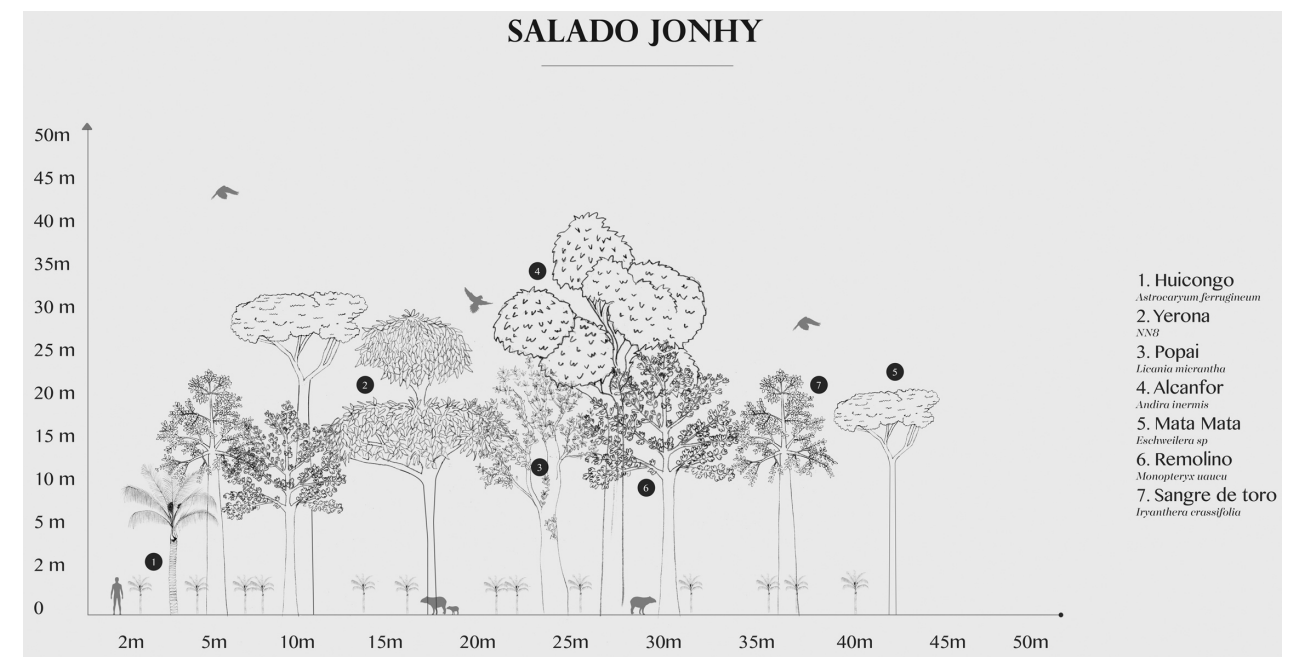

Figure 15. Jonhy saltlick in Los Kilometros. RITU. Source: the authors. 


\subsection{Statistical Analysis}

With the SPSS statistical program, an analysis was done to recognize if there exists a significant difference between the compositions of the saltlicks in both resguardos. 756 trees were used in 143 taxonomic units in a level of genera and species (when the tree was fully identified).

The univariate analysis tool was used with the fixed variable: Resguardos and Saltlick Name, and the area of inventory as the covariate, to analyze if the dependent variables: number, species, family, genera, diameter (DAP) and height stratum $(\mathrm{H})$, have significant relationships between them. According to whit the deriving results (see Table 7), there is a tendency of more number of trees, species, genera and families in Los Kilometros but statistically it is not significant.

Figure 16 shows the families distribution by percentage in the saltlicks. It was observed that there are not families that represent more than $50 \%$ of the trees in each saltlick, so there are not dominant botanical families in the composition of species in the eleven inventoried saltlicks.

Afterwards, the significance of families in the saltlicks was evaluated of both Resguardos. The analysis allowed to conclude that statistically there are no significant differences in the number of botanical families that have higher number of trees in the saltlicks (see Table 8).

Table 7. Saltlicks statistical analysis composition. Source: the authors.

\begin{tabular}{ccccc}
\hline Saltlicks & $\begin{array}{c}\text { RITU } \\
\text { estimated average }\end{array}$ & $\begin{array}{c}\text { TICOYA } \\
\text { estimated average }\end{array}$ & P Value & $\begin{array}{c}\text { statistically } \\
\text { significant }\end{array}$ \\
\hline Trees & 82.8 & 56.5 & 0.81 & No \\
Species & 32.6 & 28.8 & 0.575 & No \\
Families & 17.2 & 17.33 & 0.090 & No \\
\hline
\end{tabular}

Table 8. Families-statistical analysis composition. Source: the authors.

\begin{tabular}{ccccc}
\hline Family & $\begin{array}{c}\text { RITU. Salticks } \\
\text { estimated average }\end{array}$ & $\begin{array}{c}\text { TICOYA. Salticks } \\
\text { estimated average }\end{array}$ & P Value & $\begin{array}{c}\text { statistically } \\
\text { significant }\end{array}$ \\
\hline Arecaceae & 13.5 & 18.9 & 0.102 & No \\
Fabaceae & 14.3 & 7.2 & 0.096 & No \\
Lauraceae & 4.5 & 2.2 & 0.640 & No \\
Myristicaceae & 4.1 & 10.7 & 0.096 & No \\
Sapotaceae & 6.2 & 2.5 & 0.415 & No \\
Lecythidaceae & 7.85 & 7.97 & 0.999 & No \\
Bombacaceae & 2.2 & 0 & 0.232 & No \\
Burceraceae & 2.9 & 0 & 0.154 & No \\
Euphorbiaceae & 1.4 & 0.88 & 0.575 & No \\
Annonaceae & 1.1 & 2.55 & 0.488 & No \\
Anacardiaceae & 0 & 1.2 & 0.544 & No \\
Moraceae & 0 & 1.7 & 0.450 & No \\
Meliaceae & 0 & 1.85 & 0.544 & No \\
Tiliaceae & 0 & 1.4 & 0.45 & No \\
\hline
\end{tabular}



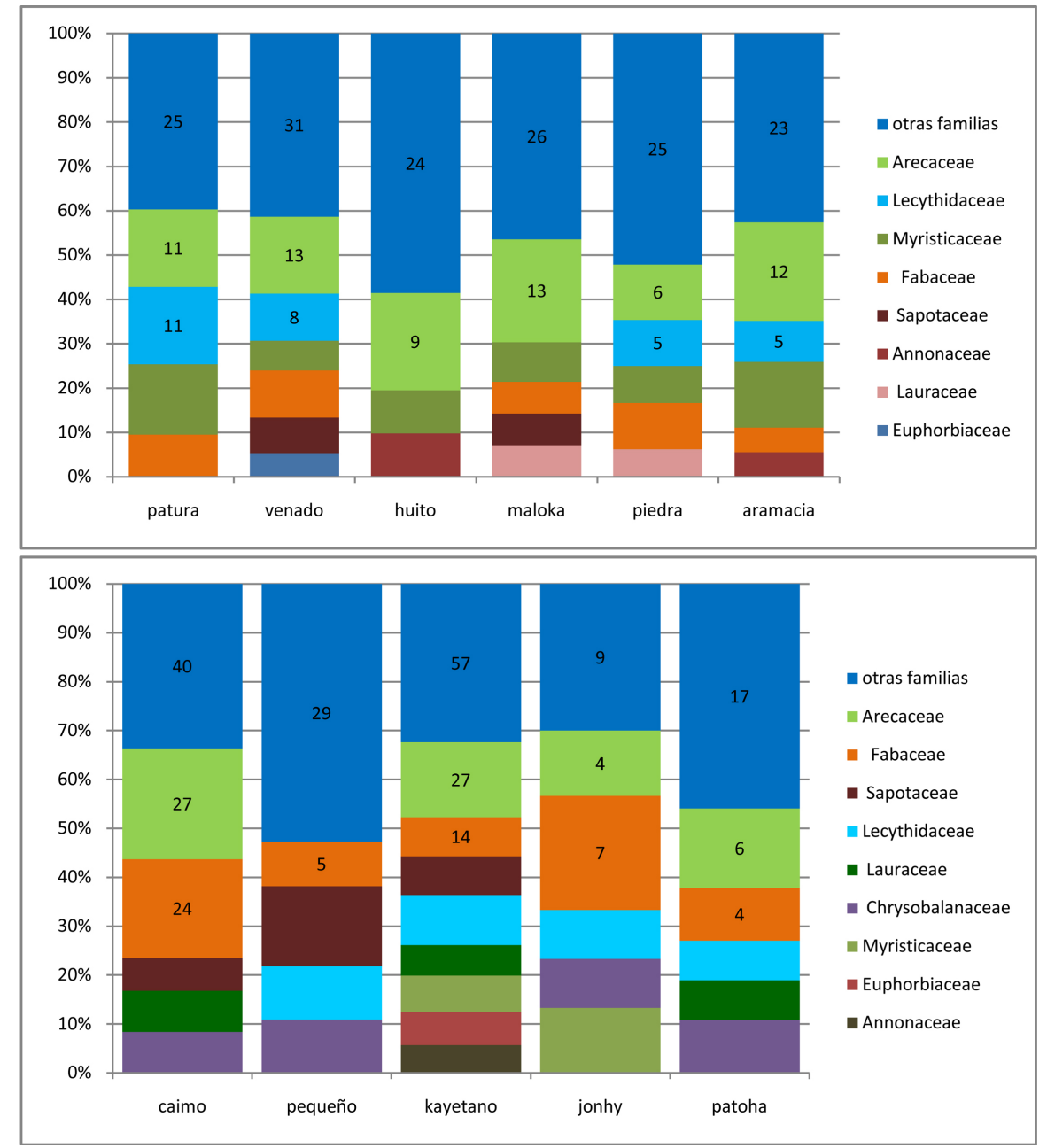

Figure 16. Up: Distribution graphic with principal botanical families in SMA. Down: Distribution graphic with the principal botanical families in Los Kilometros. Source: The authors.

The saltlicks in SMA have more number of trees without any dominant families in Arecaceae, Fabaceae and Myristicaceae. The saltlicks in Los Kilometros have more number of trees without having dominant families in Arecaceae, Fabaceae and Lecythidaceae.

In the case of botanical genres, there are not significant differences between the resguardos.

\subsection{Biodiversity Indices}

The values of the indices for the sample saltlicks in both Resguardos are shown in Table 9, where it can be observed that:

Shanon-Weaver Diversity Index: Venado, Maloka and Piedra saltlicks have a high biodiversity, their index is more than 3.0, while in the other saltlicks, the result are near of 3.0, which indicates that this last saltlick environment is still with good biodiversity but not as highly as the first three.

Caimo and Kayetano saltlicks have high biodiversity, their indices are higher 
Table 9. Saltlicks indices. Source: the authors.

\begin{tabular}{cccccc}
\hline \multirow{2}{*}{ Resguardo } & saltlick & \multicolumn{5}{c}{ Index } \\
\cline { 3 - 6 } & & diversity & Dominance & Equity & richness \\
\hline \multirow{2}{*}{ SMA_TICOYA } & 2.75 & 0.07 & 0.88 & 5.88 \\
& Venado & 3.28 & 0.04 & 0.92 & 8.24 \\
& Huito & 2.70 & 0.07 & 0.90 & 5.46 \\
& Maloka & 3.16 & 0.03 & 0.95 & 7.12 \\
& Piedra & 3.09 & 0.03 & 0.95 & 7.05 \\
& Aramacia & 2.78 & 0.06 & 0.91 & 5.52 \\
& Caimo & 3.22 & 0.07 & 0.83 & 9.70 \\
& Pequeño & 2.86 & 0.05 & 0.92 & 5.65 \\
Los Kilometros-RITU & Kayetano & 3.93 & 0.02 & 0.93 & 13.16 \\
& Jonhy & 2.76 & 0.04 & 0.95 & 5.52 \\
& Patoha & 2.76 & 0.05 & 0.94 & 5.34 \\
\hline
\end{tabular}

than 3.0, while the other saltlicks are near 3.0, which indicates that the environments in these saltlicks have a high biodiversity.

Simpson dominance index: the sample shows little dominance of species, this is because the values of this index are close to zero. That is good because indicates that in this saltlicks don't exist dominant species

Pielou Equity Index. In all saltlicks this index is close to 1.0, which indicates that these habitats are equitable for all species.

Margalef $s$ richness index. The values of this index are more than 5, all these saltlicks have good species richness. The saltlick with a value more than 7 are Venado and Maloka in SMM and Caimo and Kayetano in Los Kilometros.

\section{Conclusions}

Saltlicks are of great importance for the conservation of animal and tree species with cultural and spiritual use. This approach to the composition and richness of the saltlicks forest community, contributes to the knowledge, management and conservation of their flora communities by Tikuna and Uitoto in both Resguardos.

The perception, knowledge and spiritual management of the saltlicks by the indigenous communities Tikuna and Uitoto, help their conservation and the recognition of more than 130 species of flora that help for the health and nutrition of numerous species of fauna, especially mammals such as the Tapir (Terrestrial Tapirus) and the Deer (Mazamsp).

More than 130 species of trees and palms were identified in 90 genres and 30 families in the saltlicks sample. The families with the more number of trees without being dominant are Fabaceae, Arecaceae and Lecythidaceae. There are no significant differences between the saltlicks of the Resguardos according to 
the statistical analysis.

In SMA saltlicks (TICOYA), 28 families were identified with 59 genres. The 3 families with more number of individuals are Arecaceae, Fabaceae and Myristicaceae. In Los Kilometros sector (RITU), 30 families with 67 genres were identified; the 3 families with more number of individuals are Arecaceae, Fabaceae and Lecythidaceae.

The Biodiversity within the saltlicks in both Resguardos is high, according to the measurement of the indices that show values of more or equal to 3 . The dominance index is low, due to the fact that the values of this index are close to zero. The saltlicks richness is high; the values of this index are more or equal to 5 .

The structure of the saltlicks forests concentrates their trees in diameters less than $30 \mathrm{~cm}$ of DAP and heights in strata $\mathrm{H} 3$ and $\mathrm{H} 4$ corresponding to heights between 10 - $30 \mathrm{mts}$. Under the statistical analysis, no significant differences were found for the Diameter and Height variable between the saltlicks of both Resguardos.

In saltlicks observations, it was identified that the diameters in category DAPA are common in Los Kilometros; in SMA the diameters are between the diametric categories DAP B and DAP C. For the case of the heights in Los Kilometros, a trend in tree number in strata $\mathrm{H} 2$ and $\mathrm{H} 4$ is shown. In SMA saltlicks are more in strata $\mathrm{H} 2, \mathrm{H} 3$ and $\mathrm{H} 5$.

\section{Funding}

This work is funded by FEDER funds through the Operational Programme for Competitiveness Factors-COMPETE and by National Funds through FCT-Foundation for Science and Technology under the UID/BIA/50027/2013 and POCI-01-0145-FEDER-006821.

\section{Conflicts of Interest}

The authors declare no conflicts of interest regarding the publication of this paper.

\section{References}

[1] Vershcuuren, B., Robert, W., Jeffrey, M. and Gonzalo, O. (2011) Sacred Natural Sites. Conserving Nature and Culture. UICN, London.

[2] Europarc-España (2012) El Patrimonio Inmaterial: Valores culturales y espirituales. Manual para su incorporacion e las areas protegidas. Fundacion Fernandez Bernaldez, Madrid.

[3] Saade Granados, M. and Paramo, C. (2018) Lugares Sagrados: Definiciones y amenazas. Instituto Colombiano de Antropologia e Historia, Bogota.

[4] Suarez, C. (2018) O Homem como harmonizador da energia do Universo e da terra, do visivel e do invisivel. Conferenca Lisboa: Jardim de luz, 2018. Jardimdeluz.org.

[5] ACAIPI (2015) Hee Yaia Godo Bakari. El territorio de los Jaguares de Yurupari. Vaupez. Amazonas. Gaia. Bogota.

[6] Preciado, B.J. (2003) Territorio, colonizacion y diversidad cultural en el alto Putu- 
mayo. Colombia Forestal, 8, 110-120.

https://revistas.udistrital.edu.co/ojs/index.php/colfor/article/view/3382/4919

[7] Davis, W. (2016) Los guardianes de la sabiduria ancestral (su importancia en el mundo moderno). Silaba, Medellin.

[8] Vincent, V.H.M. and Brackelaire (2012) Guardianes de la Selva (Gobernabilidad y Autonomia en la Amazonia Colombiana) Fundacion Gaia Amazonas, Bogota.

[9] Fernandez, R. and Carlos, A. (2011) El banco del Pensamiento y el banco de la negociacion. Tropenbos, Bogota.

[10] ACITAM (2008) Plan de Vida de la Asociacion de Cabildos Indigenas del Trapecio Amazonico. Puerto Nariño-Amazonas.

[11] Cassu Camps, E. (2015) El Manejo Indigena del Mundo Global: El caso de los Tikuna de Yahuarcaca. Mundo Amazonico, 6, 47-71. https://doi.org/10.15446/ma.v6n1.46061

[12] Urbina Rangel, F. (2010) Las Palabras del Origen. Breve compendio de la mitologia de los Uitotos. Ministerio de Cultura, Bogota.

[13] Santos, A.A. (2013) Percepcion Tikuna de Naane y Naüne: Territorio y cuerpo. Ms Thesis, Univesidad Nacional de Colombia. sede Amazonas.

[14] Gregorio Vasquez, J. and Verschoor, G. (2011) In Defense of Ourselves, towards the Perfections in the Relationships between the Tikuna World and the Western World. Tropenbos, Leticia.

[15] Molina, E., Espelta, J.M., Pino, J., Bagaria, G. and Armenteras, D. (2018) Influence of Clay Licks on the Diversity and Structure of an Amazonian Forest. Biotropica, 50, 740-749. https://doi.org/10.1111/btp.12568

[16] Juan, C. (2012) Natural Licks and People: Towards an Understanding of the Ecological and Social Dimensions of Licks in the Colombian Amazon. PhD Thesis, University of Kent, Canterbury.

[17] UNAL (2017) Ojos de Sal. Elaboracion de estudios de detalle para la proteccion de humedales. Universidad Nacional de Colombia sede Medellin.

[18] Maldonado, A.M. (2012) Hunting by Tikunas in the Southern Colombian Amazon. LAP Lambert Academic Publishing, Puerto Nariño.

[19] DNP (2010) Los Pueblos Indigenas de Colombia En el Umbral del Nuevo Milenio. Departamento de Planeacion Nacional-Colombia Bogota.

[20] Rodriguez, C.F. and Clara, V.D.H.M. (2011) El Bosque intervenido: Conservacion en territorios indigenas de la Amazonia Colombiana. Colombia Amazonica N4.

[21] Ministerio, C. (2009) Caracterizacion y situacion actual de los Pueblos indigenas. Ministerio de cultura, Bogota.

[22] Rojas, E.M.J. (2013) Carbon Allocation in North-Western Amazon Forests Colombia. PhD Thesis, Universidad Politecnica de Madrid, Leticia.

[23] Garcia, C.L. (2005) Ticunas brasileros, colombianos y peruanos. Etnicidad y nacionalidad en la region de fronteras de alto Amazonas/Solimoes. $\mathrm{PhD}$ Thesis, CEPPAC, Brasilia.

[24] AZCAITA (2008) Plan de Vida de los Pueblos Tikuna, Uitoto, Cocama y Yagua. AZCAITA, Leticia.

[25] Barrero, C.M.L. (2004) Efectos de la Accion humana sobre la frecuencia y uso de los salados por las Dantas (Tapirus terrestres) en el sureste del Trapecio Amazonico Colombiano. Ms Thesis, Universidad Nacional de Colombia, sede Leticia.

[26] ATICOYA (2007) Actualizacion del Plan de vida de los Pueblos Tikuna, Cocama y 
Yagua. Puerto Nariño.

[27] DANE (2007) Colombia una Nacion Multicultural, su diversidad etnica. Departamento Administrativo Nacional de Estadistica, Bogota.

[28] Narvaez, L.H. and Olmos, J.R. (1990) Caracterizacion fitoedafologica de algunos salados en el Parque Nacional Amacayacu. Thesis, Universidad Nacional de Colombia.

[29] Naidu, M.T. and Kimar, O.A. (2016) Tree Diversity, Stand Structure, and Community Composition of Tropical Forests in Eastern Ghats of Andhra Pradesh. Journal of Asia Pacific Biodiversity, 9, 328-334. https://doi.org/10.1016/j.japb.2016.03.019

[30] Moreno, N.P., et al. (1997) Historias Tikunas de las Selvas del Amacayacu (Plantas, seres y saberes). Organizacion Yulik Airu, Puerto Nariño. 